\title{
POLYMERASE CHAIN REACTION IN DETECTING Leishmania sp IN SYMPTOMATIC AND ASYMPTOMATIC SEROPOSITIVE DOGS
}

\author{
SOARES M. J. V. (1), MORAES J. R. E. (1), ROSELINO A. M. F. (2)
}

(1) Department of Veterinary Pathology, DPVE, School of Agrarian and Veterinary Sciences, FCAV, São Paulo State University, UNESP, Jaboticabal, São Paulo, Brazil; (2) Department of Medical Clinic, Ribeirão Preto School of Medicine, São Paulo University, USP, Ribeirão Preto, São Paulo, Brazil.

\begin{abstract}
In human and canine renal histological studies of visceral leishmaniasis $(\mathrm{VL})$, the etiological agent is rarely found in situ. The objective of this study was to evaluate PCR in identifying the etiological agent in spleen, liver, lymph node, and kidneys of VL-seropositive dogs. Twenty-five symptomatic (case group) and 15 asymptomatic (control group) VL-seropositive dogs of different breeds, sexes, and ages from Teresina, Piauí State, Brazil, were used. Serologic diagnosis was made by enzyme-linked immunosorbent assay and indirect immunofluorescence test. Animals were subjected to euthanasia and necropsy. Renal fragments were immersed in buffered formaldehyde solution. Spleen, liver, lymph node, and kidney samples were collected and frozen at $-70^{\circ} \mathrm{C}$ until DNA extraction. After dehydration and diaphanization, renal fragments were infiltrated and embedded in paraffin, cut at 3 $\mu \mathrm{m}$, and stained with hematoxylin-eosin (HE). DNA amplification used an automatic thermocycler with specific Leishmania primers. All case-group dogs and 2 controls showed positive results in spleen, liver, or lymph node PCRs. There was a significant difference by Fisher exact test. In symptomatic seropositive dogs, renal histopathological evaluation showed one animal (4\%) with amastigote forms of Leishmania in inflammatory infiltrate, and kidney PCRs detected Leishmania DNA in eight animals (32\%). The conclusion was that PCR is more precise than the conventional histopathology in detecting the Leishmania parasite in kidney.
\end{abstract}

KEY WORDS: dogs, Leishmania, PCR, kidney.

\section{CORRESPONDENCE TO:}

JULIETA RODINI ENGRÁCIA DE MORAES, Laboratório de Patologia Experimental e Comparada, Departamento de Patologia Veterinária, FCAV/UNESP, Via de Acesso Professor Paulo Donato Castellani, Km 5, 14884-900, Jaboticabal, SP, Brasil. Phone: (016) 3209 2662. Email: jrmoraes@fcav.unesp.br 


\section{INTRODUCTION}

In Brazil, visceral leishmaniasis (Kala-azar) is caused by the protozoan parasite Leishmania (Leishmania) chagasi of the Kinetoplastida order and Trypanosomatidae family (16). It is an anthropozoonosis transmitted to man or other susceptible animals by Lutzomyia longipalpis (5).

Leishmania chagasi promastigotes can be found in the digestive tract of invertebrate hosts, and amastigotes in the macrophage cytoplasm of vertebrate hosts (16).

Diagnosis of canine visceral leishmaniasis is complex for two main reasons: the clinical signs are diverse and similar to other diseases; and the immunological appearance is nonspecific. Today, there is no diagnostic test that can offer $100 \%$ specificity and sensitivity (12).

Several types of diagnostic test are used, including clinical examination, and parasitological, immunological and molecular methods.

The clinical manifestations of leishmaniasis depend on the complex interactions between the virulence characteristics of the infecting Leishmania species and the host immune response (13).

Polymerase chain reaction (PCR) allows amplification (in vitro replication) of specific DNA segments from specifically annealed oligonucleotides (primers) on the edges of the target region. The reaction depends on thermostable polymerase DNA and occurs over several cycles, each typically consisting of denaturation, annealing, and extension (15).

Leishmania are members of the Kinetoplastide order, they have a special structure in the mitochondria containing extranuclear DNA, called kinetoplast (kDNA). Leishmania genus has a region of approximately 200 base pairs kept in the different species, and the remaining sequence varies between species and subspecies (1). The kDNA forms a complex network of circulating molecules, the minicircles and maxicircles, corresponding to approximately $15 \%$ to $35 \%$ of the total cell DNA (2).

With the technological advances in molecular biology, it is possible to identify Leishmania in cases of subclinical diseases and in those with few parasites, helping treatment follow-up and a more precise evaluation of its prevalence in endemic areas (15).

Leishmania DNA has been detected in different clinical samples from cases of visceral and cutaneous leishmaniasis in man and canine $(6,7,9,10,14,17)$. In 
research with $L$. donovani in humans, the parasite was detected in 21 of 22 patients by PCR using bone marrow and blood samples (6).

In general, the etiological agent is not commonly identified in renal histological studies (11). We found no reports in literature using PCR to detect Leishmania in the kidney.

Previous studies have not identified the parasite in renal histological sections. The scope of this study was to evaluate parasite presence by PCR in the kidneys of dogs with visceral leishmaniasis (VL) and in the spleen, liver, and lymph node of symptomatic and asymptomatic VL-seropositive dogs.

\section{MATERIALS AND METHODS}

\section{Animals}

Seventy-three dogs of different breeds, ages and sexes, caught by the Zoonosis Control Center in Teresina, Piauí State, between January and March 2002, were evaluated. They were all subjected to enzyme-linked immunosorbent assay and indirect immunofluorescence test. Forty VL-seropositive dogs were randomly distributed into two groups.

The case group consisted of 25 VL-seropositive dogs with clinical manifestation of the disease. The control group consisted of $15 \mathrm{VL}$-seropositive dogs without any clinical signs of the disease at physical examination.

Renal histology, and spleen, liver, lymph node and kidney PCR were evaluated in both groups.

\section{Clinical samples}

Animals were subjected to euthanasia, and renal parenchyma fragments were collected for histopathology. Spleen, liver, lymph node, and kidney samples were collected and frozen at $-70^{\circ} \mathrm{C}$ until DNA extraction.

\section{Renal histology}

After dehydration and diaphanization, renal fragments were infiltrated and embedded in paraffin, cut at $3 \mu \mathrm{m}$, placed on slides, stained with hematoxylin-eosin (HE), and examined by light microscopy. 


\section{Polymerase Chain Reaction (PCR)}

DNA extraction from spleen, liver, lymph node, and kidney (cortical and medullar region) samples was performed with approximately $25 \mathrm{mg}$ of tissue. The QIAamp DNA Mini Kit was used.

Amplification was performed using an automatic thermocycler (Applied Biosystems 9700), with each tube containing $25 \mu \mathrm{l}$ Taq PCR Master Mix Kit, $0.25 \mu \mathrm{l}$ each of $5{ }^{`}-(\mathrm{G} / \mathrm{C})(\mathrm{G} / \mathrm{C})(\mathrm{C} / \mathrm{G}) \mathrm{CC}(\mathrm{A} / \mathrm{C}) \mathrm{CTAT}(\mathrm{A} / \mathrm{T}) \mathrm{TTACACCCAACCCC}-3^{`}$ and 5`-GGGGAGGGGCGTTCTGCGAA-3` primers (Ultrachem), and $3 \mu$ of DNA from spleen, liver, lymph node, and kidney fragment samples.

Each assay contained a negative control, in which no DNA was added to the reaction mixture, and a positive control, in which parasite DNA (obtained from Leishmania donovani culture) was included as a template in the PCR.

The mixture was incubated at $94^{\circ} \mathrm{C}$ for $3 \mathrm{~min}$ and $30 \mathrm{~s}$; followed by 35 cycles of $30 \mathrm{~s}$ at $93^{\circ} \mathrm{C}, 1 \mathrm{~min}$ at $60^{\circ} \mathrm{C}, 1 \mathrm{~min}$ at $72^{\circ} \mathrm{C}$. At the end of the PCR cycles, all tubes were incubated for $10 \mathrm{~min}$ at $72^{\circ} \mathrm{C}$ and then at $4^{\circ} \mathrm{C}$.

After thermocycling, the reactions were separated by electrophoresis ( $80 \mathrm{~V}$ for 50 min) in $1.5 \%$ agarose gel with Tris/Borate/EDTA (TBE) buffer. Gel was stained with ethidium bromide and photographed under ultraviolet illumination.

\section{Statistics}

PCR results were compared by the Fisher exact test using Statistical Analysis System (SAS). The other data were analyzed by frequency of occurrence.

\section{RESULTS}

All case-group animals (symptomatic seropositive, $n=25$ ) were PCR positive in spleen, liver, or lymph node. Only two control-group animals (asymptomatic seropositive, $n=15$ ) were PCR positive in the same organs. The Fisher exact test showed significant difference at 1\% probability between both groups (Table 1).

Eight case-group and no control-group animals were PCR positive in renal tissues. There was a significant difference at $5 \%$ probability between both groups by the Fisher exact test (Table 1).

Renal histopathological evaluation of symptomatic animals (case) showed that $4 \%$ $(1 / 25)$ had Leishmania in the inflammatory infiltrate, and PCR evaluation detected Leishmania DNA in the kidneys of $32 \%(8 / 25)$ dogs. Interstitial inflammatory 
mononuclear cells with macrophages were found in this infiltrate, including amastigote forms of Leishmania sp in their cytoplasm (Figure 1). The electrophoresis analysis indicated the amplified products of Leishmania in the kidney (Figure 2).

Table 1. PCR of symptomatic $(n=25)$ and asymptomatic $(n=15)$ VL-seropositive dogs from Teresina, Piauí State, Brazil, 2002.

\begin{tabular}{|c|c|c|c|c|c|}
\hline \multirow[t]{2}{*}{ PCR Positive } & \multicolumn{2}{|c|}{ symptomatic } & \multicolumn{2}{|c|}{ asymptomatic } & \multirow[t]{2}{*}{$p$ value } \\
\hline & $\mathrm{N}^{\mathrm{O}}$ & $\%$ & $\mathrm{~N}^{\mathrm{O}}$ & $\%$ & \\
\hline Spleen, liver, or lymph node & 25 & 100 & 2 & 13.33 & $<0.000$ \\
\hline Kidneys & 8 & 32 & 0 & 0 & 0.0162 \\
\hline
\end{tabular}

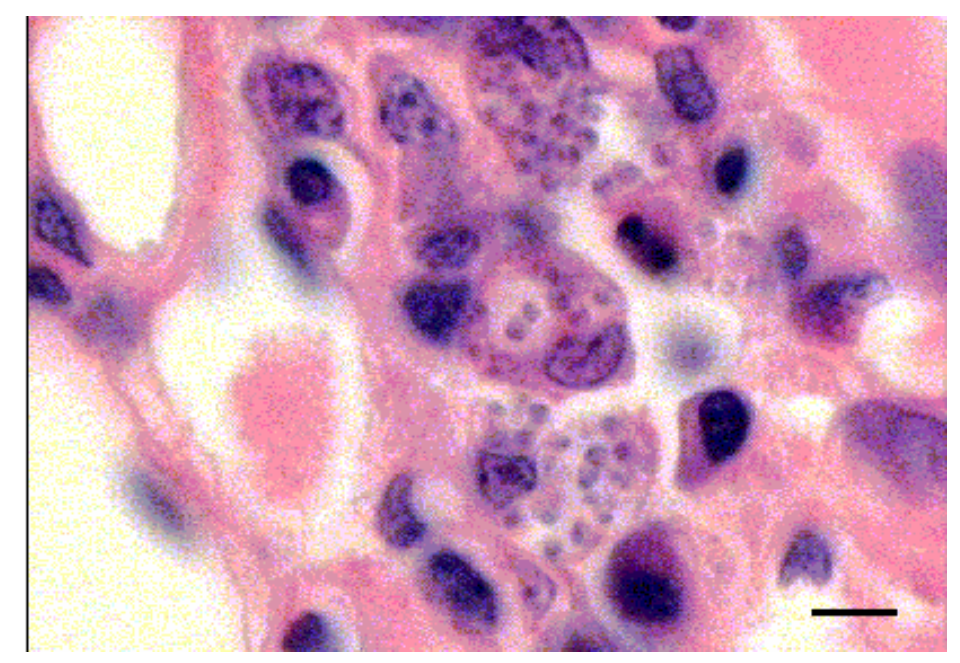

Figure 1. Histopathological aspects of the kidney in symptomatic VL-seropositive dogs. The infiltrate showed interstitial inflammatory mononuclear cells with macrophages including amastigote forms of Leishmania sp in their cytoplasm. HE staining. Bar: $5 \mu \mathrm{m}$. 


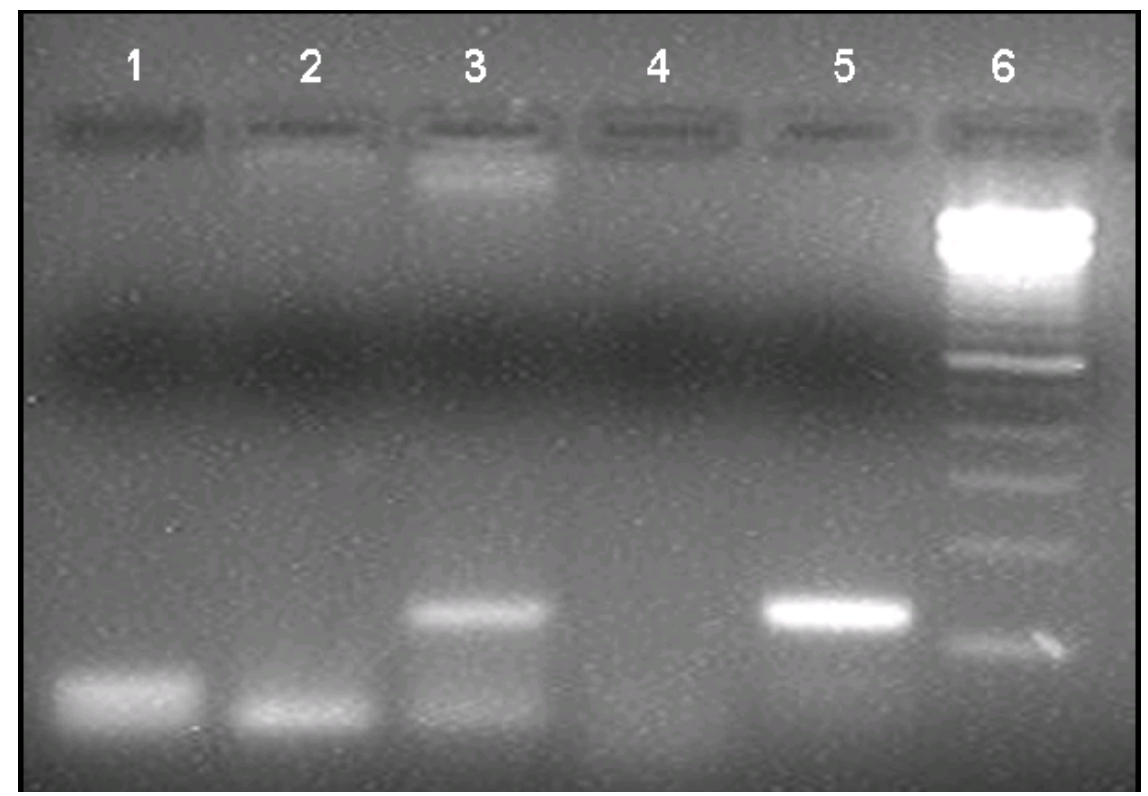

Figure 2. Electrophoresis in $1.5 \%$ agarose gel stained with ethidium bromide, showing amplification products (120 bp) from specific Leishmania primers. 1. Negative control; 2. Blood sample; 3. Right kidney sample; 4. Left kidney sample; 5. Positive control; 6. Molecular weight marker.

\section{DISCUSSION}

The animals in this study were naturally infected and at different stages of the disease. In all symptomatic VL-seropositive dogs (25/25), Leishmania sp was detected in mononuclear phagocytic system organs (spleen, liver, or lymph node) by PCR. In asymptomatic seropositive dogs, 13.33\% (2/15) were PCR positive in the same organs. There was a significant difference between both groups by the Fisher exact test. This suggests that dogs with disease symptoms should present a higher parasite load than those asymptomatic. A PCR study on blood and bone marrow aspirate found Leishmania parasites in 18\% (4/22) of clinically symptomatic dogs and in 7.6\% (40/523) of asymptomatic dogs (14). In research with L. donovani in humans, the parasite was detected in 21 of 22 patients by PCR using bone marrow and blood samples (6). With technical advances in molecular biology, it is possible to identify Leishmania in cases of subclinical diseases and in those with few parasites, improving the precision of prevalence evaluation in endemic areas (15).

Renal histopathological evaluation showed that one animal (4\%) had amastigote forms of Leishmania in inflammatory infiltrate, and PCR detected Leishmania (32\%) in renal fragments of symptomatic VL-seropositive dogs. This confirmed that PCR was a more precise test for detecting the parasite in this organ. Several authors have 
reported parasite absence in renal histopathological evaluation $(3,4,8,11)$. None of the consulted literature shows this protozoan in renal tissue by PCR.

In conclusion, there were more positive results by PCR in symptomatic seropositive dogs. The VL etiological agent could be involved in the histopathology of glomerular lesions, and PCR is more precise than conventional histopathology in detecting the Leishmania parasite.

\section{ACKNOWLEDGMENTS}

To FAPESP for financial support; to the Zoonosis Control Center of Teresina, Piauí State for donating the animals; to Maria Inês Yamazaki de Campos and Francisca de Assis Ardisson for preparing the histological sections; and to Sandra Silva Rodrigues for assistance with PCR.

\section{REFERENCES}

1 ASHFORD D.A., BOZZA M., FREIRE M., MIRANDA J.C., SHERLOCK I., EULÁLIO C., LOPES U., FERNANDES O., DEGRAVE W., BARKER Jr. R.H., BADARO R., DAVID JR. Comparison of the polymerase chain reaction and serology for detection of canine visceral leishmaniasis. Am. J. Trop. Med. Hyg., 1995, 53, 251-5.

2 BREWSTER S., BARKER DC. Analysis of minicircle classes in Leishmania (Viannia) species. Trans. R. Soc. Trop. Med. Hyg., 2002, 96, 55-63.

3 CARAVACA F., MUNÕZ A., PIZARRO JL., SANTAMARIA JS., ALONSO JF. Acute renal failure in visceral leishmaniasis. Am. J. Nephrol., 1991, 11, 350-2.

4 COSTA F.A.L. Patologia e imunopatogenia da nefropatia da leishmaniose visceral canina. São Paulo: Universidade de São Paulo, Faculdade de Medicina Veterinária e Zootecnia, 2001. 129p. [Tese - Doutorado]

5 FEITOSA M.M., IKEDA F.A., LUVIZOTTO M.C.R., PERRI S.H.V. Aspectos clínicos de cães com leishmaniose visceral no município de Araçatuba - São Paulo (Brasil). Clín. Vet., 2000, 5, 36-44.

6 HU X., YANG W., LU H., YAN H., CHENG J., MA Y., JIN B., ZHANG T. Sequencing a specific kinetoplast DNA fragment of Leishmania donovani for polymerase chain reaction amplification in diagnosis of Leishmaniasis in bone marrow and blood samples. J. Parasitol., 2000, 86, 822-6. 
7 LACHAUD L., CHABBERT E., DUBESSAY P., DEREURE J., LAMOTHE J., DEDET JP., BASTIEN P. Value of two PCR methods for the diagnosis of canine visceral leishmaniasis and the detection of asymptomatic carriers. Parasitology, 2002, 125, 197-207.

8 MARTINELLI R., SILVEIRA MA., ROCHA H. Glomerulonefrites associadas a infestações parasitárias. In: SOARES V., ALVES MAR., BARROS RT. Glomerulopatias: patogenia, clínica e tratamento. São Paulo: Sarvier, 1999: 206-13.

9 MATHIS A., DEPLAZES P. PCR and in vitro cultivation of Leishmania spp. in diagnostic samples from humans and dogs. J. Clin. Microbiol., 1985, 33, 1145-9.

10 MEDEIROS ACR. Leishmaniose tegumentar americana: casuística e implantação de PCR para diagnóstico, HC-FMRP-USP, 1978-1998. Ribeirão Preto: Universidade de São Paulo, Faculdade de Medicina de Ribeirão Preto, 1999. 174p. [Master Dissertation].

11 NICODEMO EL., DUARTE MIS., NICODEMO AC., AMATO NETO V. Aspectos clínico-laboratoriais da nefrite intersticial da leishmaniose visceral. Rev. Paul. Med., 1984, 102, 19-22.

12 NOLI C. Leishmaniosis canina. Waltham Focus, 1999, 9, 16-24.

13 PEARSON R.D., SOUSA A.Q. Clinical spectrum of leishmaniasis. Clin. Infect. Dis., 1996, 22, 1-11.

14 REITHINGER R., LAMBSON BE., BARKER DC., DAVIES CR. Use of PCR to detect Leishmania (Viannia) spp. in dog blood and bone marrow. J. Clin. Microbiol., 2000, 38, 748-51.

15 RODRIGUES EHG. Validação de abordagens moleculares para o diagnóstico da leishmaniose tegumentar americana em Pernambuco. Recife: Centro de Pesquisas Aggeu Magalhães, Fundação Oswaldo Cruz, 2000. 70p. [Masters Dissertation]

16 SANTA ROSA I.C.A., OLIVEIRA I.C.S. Leishmaniose visceral: breve revisão sobre uma zoonose reemergente. Clín. Vet., 1997, 2, 24-8.

17 SUFFIA I., FERRUA B., STIEN X., MOGRABI B., MARTY P., ROUSSEAU D., FRAGAKI K., KUBAR J. A novel Leishmania infantum recombinant antigen which elicits interleukin 10 production by peripheral blood mononuclear cells of patients with visceral leishmaniasis. Infect. Immun., 2000, 68, 630-6. 